ACTA THERIOLOGICA

Vol. 31, 20: 257-270, 1986

\title{
Can Dietary Quality of Free-ranging Ungulates Be Simply Determined from Faecal Chemistry?
}

\author{
R. J. PUTMAN \& G. J. HEMMINGS
}

\begin{abstract}
Putman R. J. \& Hemmings G. J., 1986: Can dietary quality of free-ranging ungulates be simply determined from faecal chemistry? Acta theriol., 31, 20: 257-270 [With 5 Tables]

Feeding trials with a number of ungulate species in South Africa led Erasmus et al. (1978) to propose that linear relationships might exist between content of diet and content of dung for a number of key dietary nutrients, and that thus chemical analysis of dung might provide a simple method for determining available forage quality. These suggestions are tested, using three temperate ruminant species (fallow, sika and roe deer) and one non-ruminant (free-ranging domestic horses). Dietary content of dung in terms of a number of nutrients was related to dietary quality of ingesta (reconstructed from faecal dissection). Significant linear relationships were found amongst the deer for $\mathrm{N}, \mathrm{K}, \mathrm{Ca}$ content of diet and dung, but not for $\mathrm{P}, \mathrm{Mg}$ or lignin; a linear relationship was established in the horse only for lignin. The implications of these results for simple determination of fcrage quality are discussed.

[Department of Biology, Building 44, The University, Southampton, Great Britain]
\end{abstract}

\section{INTRODUCTION}

Estimating the nutritional quality of the diet of a free-ranging herbivore is one of the most difficult of tasks facing the ecologist or practising wildlife manager. Conventional techniques available are chemical analysis of subsamples obtained through fistulation (e.g. Engels et al. 1971, 1975), chemical analysis of gut contents from culled animals (e.g. Staines \& Crisp, 1978, Staines et al. 1982) or analysis of vegetational samples taken by hand from the various forage species known to be taken (various workers). Fistulation is an expensive and somewhat risky technique of very limited application for free-ranging animals; in addition the sample of ingesta derived may not be truly representative of the full diet. Chemical analysis of rumen or stomach contents is restricted to samples from culled animals - and therefore generally restricted to certain seasons; in addition, the effects of partial digestion on nutrient status of food materials is unknown. Estimate of dietary quality from chemical analysis of forage samples plucked by hand, while perhaps the most commonly used technique, is fraught with error. The human may sample different parts of the plant from those 
taken by a grazing animal; even if this grazing could be accurately simulated, the fact that the sample taken by the human experimenter is available to be plucked and has not already been removed by the grazer suggests that it may be of lower quality than that which has been eaten; where comparisons have been made, nitrogen levels in samples of forage actually ingested by red deer were consistently higher than those in forage samples taken by hand (Van de Veen 1979).

More recently, it has been suggested by Erasmus et al. (1978) that, amongst herbivores, an estimate of dietary quality of the ingesta may simply be determined from analysis of the nutrient status of faeces. In feeding trials with Springbok (Antidorcas marsupialis), Dorper sheep and Merino sheep, Erasmus et al. demonstrate a linear relationship between chemical content of dung and ingesta for both lignin and protein nitrogen: perhaps the most important determinants of dietary quality. If dietary quality could indeed by assessed accurately in this way, from simple chemical analysis of easily-collected faecal material, the implications are tremendous.

In order to test the claims of Erasmus et al. (1978) beyond the laboratory, we examined the relationship between dietary and faecal content of lignin, nitrogen and four additional key nutrients $(\mathrm{K}, \mathrm{P}, \mathrm{Mg}, \mathrm{Ca})$ for four free-ranging temperate ungulate species: three ruminants (roe, fallow and sika deer: Capreolus capreolus, Dama dama, and Cervus nippon) and one non-ruminant (domestic horses: Equus).

\section{METHODS}

Relationships between the nutrient content of diet and dung investigated in the present study could not be based on controlled feeding trials like those described by Erasmus et al. (1978) since all animals studied were free-ranging and free-feeding. However, dietary species composition could be determined from microscopical analysis of freshly collected faecal samples and then corrected by values determined in vitro for the nutrient status of the different forages contained, to offer some index of dietary quality of ingesta (Methods A). This index could then be related to the direct nutrient status of the dung itself (Methods B).

Faecal depositions from free-ranging horses, fallow and sika deer were collected in the New Forest, Hampshire between 1977 and 1981 in the course of other studies (Putman et al. 1982; Putman 1984a; Mann, 1983); roe droppings were collected from Chedington Wood in Dorset and Porton Down, Wiltshire (Johnson, 1984). Samples were taken at 2 monthly intervals over one year (to give a range of dietary quality available, within each species). Thus, fallow, sika and roe droppings were analysed for December, February, April, June, August and October (1980); horse dung for those same months during 1979-81. For each species/month, one pellet group was taken; each pellet group was macerated and divided into 
two subsamples - one (subsample A) taken for dietary reconstruction (A), the other retained for direct chemical analysis subsample (B).

\subsection{Dietary Reconstruction}

2.1.1. Species Composition of the Diet

Species composition of the diet represented by a given dung sample was determined from identification of plant cuticle remains in the dung, following standard methods, (e.g. Stewart, 1967; Stewart \& Stewart, 1970; Anthony \& Smith, 1974). Faecal material was macerated in $\mathrm{NaOH}$ to remove mucus and to clear cuticular remains. A small subsample of treated material was placed on a petri-dish, previously scored with lines to produce a $1 \mathrm{~mm}^{2}$ grid. The first 100 cuticular fragments lying on chosen grid lines were identified and recorded. A second subsample was then recorded; thus in total 200 cuticular fragments for each sample were identified.

Because of the problems in a mixed diet of estimating from faecal analysis the relative intake of different forage types due to differential digestibility of different diet items, results were corrected for differential digestibility after Putman et al. (1982) and Putman (1984). In essence, individual fragment counts of each plant species recorded in the faecal sample are multiplied by $1 /(1-$ species specific digestibility of that forage plant derived in vitro) to approximate to a more accurate estimate of relative proportion in the ingesta. "Corrected" fragment counts were then used to derive percentage species composition of the diet.

\subsubsection{Digestibility of Forages}

Monthly samples of the various forage species consumed by the herbivores were collected in the same areas as those used for faecal collection at the same time as faecal collections were made. Dry matter digestibility was determined in vitro by successive incubation in solutions of pepsin and fungal cellulase (method after Jones \& Hayward, 1975). Two hundred $\mathrm{mg}$ of the ground herbage was incubated with $20 \mathrm{ml}$ of $0.2 \%$ pepsin in $0.1 \mathrm{~N}$ hydrochloric acid for $24 \mathrm{~h}$ at $40^{\circ} \mathrm{C}$ in a screw cap bottle. The supernatant was removed by filtration through a filter stick (gas distribution tube, porosity 2, disc diameter $14 \mathrm{~mm}$ ) the stick rinsed and the volume made up to ca. $20 \mathrm{ml}$ with cellulase solution (125 $\mathrm{mg}$ cellulase in $20 \mathrm{ml}$ phosphate citrate buffer $\mathrm{pH}$ 4.6). The bottle was returned to the incubator for a further $48 \mathrm{~h}$ at $40^{\circ} \mathrm{C}$ (shaking by inversion night and morning). The indigestible residue was then isolated by filtration through a tared filter paper, and the amount digested calculated as a percentage of the original dry matter.

Jones and Hayward (1975), have related enzymic digestibility by this method to true in vivo digestibility in sheep, and present a regression equation for derivation of equivalent digestibility as $y=0.54 x+35.0 \quad(r=0.93)$. Most of our digestibility values lie well outside, and below, the range of enzymic digestibilities over which this relationship has been calculated; We are thus unable to employ the regression equation here. Instead a straight ratio of in vivo/enzymic digestibility has been calculated for the mean values presented by Jones and Hayward and this simple ratio (as 1.143) is used here to convert enzymic values to true digestibilities for the ruminants. Jones and Hayward determined the relationship between in vivo digestibilities and enzyme digestibility using sheep. In vivo digestibilities calculated for our figures thus strictly represent digestibility of our forages to sheep but are taken here to approximate to digestibilities for the three deer species of our studies. Further correction is necessary however to derive figures for digestibility of the forages to horses, whose digestive capacity 
may be expected to differ markedly from that of the three ruminants. In a review of equine nutrition, Hintz (1969) presents figures relating the digestibilities of forage in cattle and horses to those of sheep; his figures suggest TDMD of particular forages for horses are $0.92 \times$ the sheep values. In vivo digestibilities for our various forages have thus been multiplied by this constant factor of 0.92 , in calculating digestibilities for horses.

\subsubsection{Chemical Composition of Forages ${ }^{1}$}

Vegetational samples were further analysed for $\mathrm{N}, \mathrm{P}, \mathrm{K}, \mathrm{Ca}, \mathrm{Mg}$ and lignin. Samples for analysis of $\mathrm{N}, \mathrm{P}, \mathrm{K}, \mathrm{Ca}$ and $\mathrm{Mg}$ were digested using a modification of the Kjeldahl digest as recommended by Allen (1974). In this method a mixture of sulphuric acid and hydrogen peroxide is used with a catalyst of lithium sulphate and selenium.

Potassium was determined by flame photometry, and calcium and magnesium by atomic absorption spectrophotometry, using lanthanum chloride solution to suppress possible interference effects. Phosphorus and nitrogen were determined colorimetrically using a Technicon autoanalyser. The phosphorus method employs ammonium molybdate and ammonium metavanadate as reagents, and produces a stable yellow colour which is read at $450 \mathrm{~nm}$. The nitrogen method is based on the reaction of ammonium ions with alkaline phenate and hypochlorite; on heating an intense blue colour is produced which is read at $680 \mathrm{~nm}$.

Lignin content of the vegetation was separately derived. A simple and speedy method of analysis was sought; that ultimately adopted is derived from methods advocated by Goering \& van Soest (1970). A quantity of dry, milled sample $(200-400 \mathrm{mg}$ ) was weighed and boiled for one hour in $7.5 \mathrm{ml}$ of acid detergent reagent to remove protein, fats and carbohydrates. The sample was filtered and the residue (containing cellulose and lignin) dried and reweighed. Each sample was then incubated at room temperature in a saturated solution of $\mathrm{KMnO}_{4}$; this effectively removes the lignin in the sample, leaving cutene and cellulose. Unfortunately $\mathrm{KMnO}_{4}$ reacts with the organic component of the sample to form a precipitate of insoluble manganese oxide; samples were therefore rinsed in acid hydrogen peroxide solution to remove this precipitate before drying and reweighing. Dry weight of residual cutene and cellulose was subtracted from the dry weight of sample determined after incubation in acid detergent reaction to derive weight of lignin contained in the original sample.

\subsubsection{Reconstruction of Dietary Quality}

Nutrient values of the various different forage species can now be combined with proportional species composition of the diet to derive an index of nutritional quality of ingesta. In any one month, the percentage fragment count for each forage species in the diet of a given species of herbivore may be multiplied by the laboratory-determined value for content of each nutrient (derived for that particular forage in that particular geographical area in that month). These values were summed within any month over each forage species in the diet to provide a figure for the "dietary units" of any given nutrient in the ingesta represented

1 Data on forage chemistry arranged according to the season and plant species: are not included in the text but can be obtained from the author on a special request. 
by a given faecal sample. (By this time, with so many transformations performed upon the data, units are completely arbitrary - and may not be expressed in absolute terms, as, for example $\mathrm{g} \mathrm{N}$ per $\mathrm{g}$ ingested material).

\subsection{Chemical Composition of Faeces and Relationship to Dietary Quality}

The second subsample of each faecal pellet group was subjected directly to nutrient analysis, using the same methods as described above for vegetation, to determine $\mathrm{N}, \mathrm{P}, \mathrm{K}, \mathrm{Mg}, \mathrm{Ca}$ and lignin content of the dung itself. Estimated dietary value of the ingesta represented in that precise dung sample, for subsample A, was then related to the actual value of any given nutrient present in the dung itself (subsample B), to seek any, relationship of the type suggested by Erasmus et al. (1978).

\section{RESULTS}

Species composition of the various dung samples analysed for each of the four ungulate species are shown in tables $1 \mathrm{a}-4 \mathrm{a}$. In each case percentage fragment count is shown after correction for differential digestibility. Diet for roe deer is presented for 3 months only since preparation methods used for cleaning faecal material were not entirely effective for this species. Percentage fragment counts in "corrected" diets are then multiplied by the appropriate forage nutrient value (full tables of $\mathrm{N}, \mathrm{P}, \mathrm{M}, \mathrm{Mg}$ and lignin values of the different forage species are available from the author) to derive for each animal species, in each month, a total "dietary quality" of the meal represented by that dung sample in terms of each nutrient measured, (Tables $1 \mathrm{~b}-4 \mathrm{~b}$ ). Finally, chemical content of faecal material itself (as mg per g) for each species is shown in Tables $1 \mathrm{c}-4 \mathrm{c}$.

It must be stressed that dietary profiles for the four ungulate species presented in Tables 1a-4a are not intended to be taken as representing the "general" picture of diet amongst these animals. These dietary profiles recreate the specific diet represented within a particular individual set of faecal pellets (so that nutrient status of ingesta and dung may be compared for the same meal). They are not representative of the "average diet" of individual animals or whole species. Fuller descriptions. of the dietary "species norm" for each of these ungulates may be found elsewhere (Jackson 1977, Mann 1983, Putman et al. 1982, Johnson, 1984).

From these results, regressions may be calculated for each animal species, (using different monthly diets merely to provide a range of different dietary qualities) between content of ingesta for any particular nutrient (arbitrary units) and nutrient content of dung (mg per g). A linear relationship is found between values in dung and purported ingesta for potassium, calcium and nitrogen for all deer species (with. 
Table 1

Dietary reconstruction and nutrient content of dung samples for Fallow deer.

Febr. Apr. June Aug. Oct. Dec.

(a) Percentage species composition of ingesta represented in selected dung samples

\begin{tabular}{|c|c|c|c|c|c|c|}
\hline \multicolumn{4}{|l|}{ Betula } & \multicolumn{3}{|c|}{1.9} \\
\hline Quercus & & 0.7 & 0.8 & 5.2 & 17.2 & 1.6 \\
\hline (Acorn) & 1.5 & & & & & 2.7 \\
\hline Conifers & 3.0 & 21.0 & 2.1 & 3.0 & & $\begin{array}{r}19.0 \\
0.9\end{array}$ \\
\hline $\begin{array}{l}\text { Rubus } \\
\text { Hedera }\end{array}$ & & & & & & $\begin{array}{l}0.9 \\
1.4\end{array}$ \\
\hline Ulex & 12.4 & 9.7 & 2.3 & 0.9 & 2.9 & 19.6 \\
\hline Calluna/Erica & 1.5 & & 0.6 & & & 3.3 \\
\hline Other shrubs & 2.9 & 1.2 & 0.6 & 5.7 & 8.5 & 12.2 \\
\hline Agrostis tenuis & 1.3 & 0.6 & 23.1 & 9.9 & 3.1 & 0.6 \\
\hline A. setacea & 1.8 & 1.1 & 12.8 & 14.1 & 2.7 & 1.1 \\
\hline Other grasses & 26.2 & 33.6 & 37.1 & 38.0 & 16.2 & 5.5 \\
\hline Juncus sp. & 0.6 & 2.2 & 3.4 & 3.9 & 0.7 & \\
\hline Bracken and Ferns & 3.0 & 17.7 & 12.0 & 8.0 & 2.7 & \\
\hline Mosses & 44.5 & 11.0 & 1.6 & 3.6 & 42.1 & 32.0 \\
\hline Forbs & 1.2 & 1.2 & 3.5 & 7.7 & 1.9 & \\
\hline
\end{tabular}

(b) Chemical composition of the "meal" represented by the ingesta. Values (in arbitrary units) are derived by combining dietary composition from Table (a) with known forage qualities

\begin{tabular}{lrrrrrr}
\hline $\mathrm{N}$ & 1468 & 2793 & 2379 & 2091 & 1920 & 1613 \\
$\mathrm{P}$ & 125 & 175 & 178 & 138 & 146 & 121 \\
$\mathrm{~K}$ & 585 & 1074 & 1895 & 1609 & 1359 & 762 \\
$\mathrm{Mg}$ & 79 & 95 & 146 & 101 & 134 & 83 \\
$\mathrm{Ca}$ & 243 & 372 & 457 & 615 & 461 & 471 \\
Lignin & 2245 & 2201 & 1803 & 1884 & 2375 & 2247 \\
\hline
\end{tabular}

(c) Actual nutrient quality of the same dung sample (values in $\mathrm{mg} \cdot \mathrm{g}^{-1}$ except lignin which is expressed as $\%$ faecal sample by weight)

\begin{tabular}{lrrrrrr}
\hline $\mathrm{N}$ & 31.5 & 26.5 & 35.0 & 34.8 & 33.5 & 25.8 \\
$\mathrm{P}$ & 1.8 & 1.0 & 1.9 & 1.7 & 1.2 & 1.5 \\
$\mathrm{~K}$ & 1.7 & 1.7 & 2.8 & 2.6 & 2.2 & 2.2 \\
$\mathrm{Mg}$ & 1.3 & 0.9 & 2.5 & 2.5 & 1.1 & 0.9 \\
$\mathrm{Ca}$ & 9.3 & 6.4 & 13.0 & 19.3 & 10.2 & 6.5 \\
Lignin & 18.3 & 18.8 & 14.5 & 20.8 & 24.3 & 19.5 \\
\hline
\end{tabular}

varying levels of significance). No such relationship is observed for these same nutrients (N, P, K, Ca) for the horse - which however shows correlations for lignin not found amongst the ruminants. In no species was a relationship observed between magnesium content of diet and dung,

Individual regression equations are not presented here (since nutrient content of presumed ingesta is, in any case, in arbitrary units). Table 5 summarises however, correlation coefficients (and significance or correlation) for each nutrient and each animal. Significance is accepted at the $10 \%$ level (because of the coarseness of the data). 
Table 2

Dietary reconstruction and nutrient content of dung samples for Sika deer.

Febr. Apr. June Aug. Oct. Dec.

(a) Percentage species composition of ingesta represented in selected dung samples

\begin{tabular}{|c|c|c|c|c|c|c|}
\hline Betula & 4.9 & & 1.9 & 4.8 & & 6.7 \\
\hline Fagus & 1.3 & 0.7 & 0.6 & 1.3 & & 2.5 \\
\hline Quercus & 4.4 & 1.6 & 0.8 & 8.3 & 14.9 & 11.1 \\
\hline (Acorn) & 1.5 & & & & 16.9 & 7.1 \\
\hline Salix & 0.7 & & & & & 2.5 \\
\hline Conifers & 37.8 & 28.8 & 5.1 & 1.1 & & 14.4 \\
\hline Rubus & 0.9 & & & & 7.4 & 5.2 \\
\hline Hedera & & 2.4 & 2.8 & 2.2 & & 1.6 \\
\hline Ulex & 22.0 & 27.2 & 9.0 & 2.5 & 2.7 & 5.9 \\
\hline Calluna/Erica & 2.2 & 0.7 & 0.6 & 0.6 & & 5.2 \\
\hline Other shrubs & 12.3 & 11.9 & 11.1 & 5.2 & 17.8 & 21.2 \\
\hline Agrostis tenuis & 1.3 & 2.0 & 4.9 & 13.2 & 6.8 & 0.7 \\
\hline A. setacea & 0.6 & 0.6 & 22.6 & 17.9 & 2.0 & 0.7 \\
\hline Molinia & & 1.9 & & 1.2 & & 2.5 \\
\hline Other grasses & 6.3 & 17.8 & 29.7 & 26.2 & 22.9 & 10.2 \\
\hline Juncus sp. & & & & 4.4 & & \\
\hline Bracken and Ferns & 3.0 & 2.9 & 0.7 & 3.3 & 1.3 & 2.5 \\
\hline Mosses & & 1.3 & 5.0 & 3.8 & 3.4 & \\
\hline Forbs & 0.6 & & 5.2 & 4.0 & 3.9 & \\
\hline
\end{tabular}

(b) Chemical composition of the "meal" represented by the ingesta. Values (in arbitrary units) are derived by combining dietary composition from Table (a) with known forage qualities

\begin{tabular}{lrrrrrr}
\hline N & 1858 & 2115 & 2425 & 2210 & 1831 & 1655 \\
$\mathbf{P}$ & 107 & 139 & 169 & 131 & 127 & 98 \\
$\mathrm{~K}$ & 739 & 942 & 1550 & 1529 & 1300 & 605 \\
$\mathrm{Mg}$ & 74 & 71 & 142 & 100 & 140 & 92 \\
$\mathrm{Ca}$ & 564 & 417 & 471 & 621 & 573 & 873 \\
Lignin & 2024 & 2079 & 1921 & 1984 & 1897 & 2092 \\
\hline
\end{tabular}

(c) Actual nutrient quality of the same dung sample (values in $\mathrm{mg} \cdot \mathrm{g}^{-1}$ except lignin which is expressed as $\%$ faecal sample by weight)

\begin{tabular}{lrrrrrr}
\hline $\mathbf{N}$ & 24 & 28 & 41 & 35 & 28 & 27 \\
$\mathbf{P}$ & 0.7 & 0.6 & 1.3 & 2.0 & 1.2 & 0.3 \\
$\mathrm{~K}$ & 2.0 & 1.2 & 2.7 & 5.4 & 1.2 & 0.7 \\
$\mathrm{Mg}$ & 1.2 & 0.8 & 1.0 & 0.9 & 0.8 & 0.6 \\
$\mathrm{Ca}$ & 10.7 & 9.3 & 11.8 & 12.5 & 10.5 & 14.2 \\
Lignin & 22.0 & 20.5 & 24.3 & 18.3 & 25.8 & - \\
\hline
\end{tabular}

\section{DISCUSSION}

Erasmus et al. (1978) in suggesting that nutrient content of dung and nutrient content of ingesta might be linearly related drew only tentative conclusions from feeding trials with a small sample (two or three individuals) of a limited number of species. The present study was initiated in order to test their conclusions in investigation of the nutrient 
Table 3

Dietary reconstruction and nutrient content of dung samples for Roe deer. Data for June, August and October were not recorded.

Febr. Apr.

Dec.

(a) Percentage species composition of ingesta represented in selected dung samples

\begin{tabular}{lrrr}
\hline Betula & 7.6 & 0.8 & 1.2 \\
Fagus & 8.2 & & 1.3 \\
Quercus & 6.1 & 1.0 & 0.7 \\
(Acorn) & 1.3 & & 1.7 \\
Salix & & & \\
Ilex & 4.7 & 6.9 & 1.1 \\
Conifers & & 0.8 & 10.1 \\
Rubus & 1.1 & & 0.7 \\
Hedera & 11.7 & 10.6 & 13.3 \\
Calluna/Erica & & & 1.4 \\
Other shrubs & 24.4 & 3.6 & 3.0 \\
Agrostis tenuis & 2.4 & 4.1 & 62.7 \\
A. setacea & & 5.1 & 2.7 \\
Other grasses & 26.0 & 36.1 & \\
Bracken and Ferns & 8.2 & 14.8 & 0.8 \\
Mosses & & & \\
Forbs & 3.9 & 15.4 & \\
& & &
\end{tabular}

(b) Chemical composition of the "meal" represented by the iningesta. Values (in arbitrary units) are derived by combining dietary composition from Table (a) with known forage qualities

\begin{tabular}{lrrr}
\hline $\mathrm{N}$ & 1999 & 2102 & 1505 \\
$\mathrm{P}$ & 157 & 228 & 95 \\
$\mathrm{~K}$ & 947 & 1197 & 481 \\
$\mathrm{Mg}$ & 100 & 105 & 139 \\
$\mathrm{Ca}$ & 842 & 494 & 1120 \\
Lignin & 1978 & 2123 & 2214 \\
\hline
\end{tabular}

(c) Actual nutrient quality of the same dung sample (values in $\mathrm{mg} . \mathrm{g}^{-1}$ except lignin which is expressed as $\%$ faecal sample by weight)

\begin{tabular}{lrrr}
\hline $\mathrm{N}$ & 26 & 35.3 & 30 \\
$\mathrm{P}$ & 7.5 & 0.6 & 3.0 \\
$\mathrm{~K}$ & 1.1 & 1.2 & 1.0 \\
$\mathrm{Mg}$ & 2.3 & 3.1 & 2.1 \\
$\mathrm{Ca}$ & 52.0 & 40.2 & 22.1 \\
Lignin & 29.3 & 29.3 & 36.7 \\
\hline
\end{tabular}

chemistry of diet and dung in a different set of four, temperate, ungulate species.

Direct feeding trials were impracticable in the present study; estimates of relative nutrient status of ingesta, for comparison with nutrient content of the related dung, were derived by a multi-step reconstruction of dietary profile from faecal dissection. Such reconstruction 
Table 4

Dietary reconstruction and nutrient content of dung samples for Horses.

Febr. Apr. June Aug. Oct. Dec.

(a) Percentage species composition of ingesta represented in selected dung samples

\begin{tabular}{lrrrrrr}
\hline Betula & 0.6 & & & & & 0.6 \\
Quercus & & 1.6 & 0.7 & & & 2.9 \\
Conifers & 1.2 & & & & & 24.4 \\
Ulex & 12.0 & 1.6 & 0.7 & 1.5 & & 1.7 \\
Caliuna/Erica & 2.0 & 1.5 & 1.2 & & 0.6 & 0.6 \\
Other shrubs & 4.7 & & 0.6 & & 7.1 & 1.3 \\
Agrostis tenuis & 10.5 & 2.1 & 13.6 & 19.5 & 7.7 \\
A. setacea & 10.3 & 14.5 & 31.7 & 15.3 & 21.9 & $\mathbf{2}$ \\
Other grasses & 29.9 & 50.0 & 43.6 & 51.3 & 43.3 & $\mathbf{2 7 . 8}$ \\
Juncus sp. & & 1.4 & 4.5 & 3.1 & 1.2 & 1.8 \\
Bracken and Ferns & 1.2 & 0.6 & 0.7 & 2.8 & 5.5 & 14.3 \\
Mosses & 26.4 & 24.5 & 2.7 & 4.5 & 17.0 & 19.3 \\
Forbs & 1.2 & 2.2 & & 2.0 & 3.3 & 0.6 \\
\hline
\end{tabular}

(b) Chemical composition of the "meal" represented by the ingesta. Values (in arbitrary units) are derived by combining dietary composition from Table (a) with known forage qualities

\begin{tabular}{lrrrrrr}
\hline $\mathrm{N}$ & 1602 & 1871 & 2447 & 2064 & 1835 & 1694 \\
$\mathrm{P}$ & 136 & 204 & 155 & 145 & 151 & 128 \\
$\mathrm{~K}$ & 626 & 829 & 1616 & 1646 & 1333 & 894 \\
$\mathrm{Mg}$ & 79 & 85 & 95 & 101 & 88 & 102 \\
$\mathrm{Ca}$ & 279 & 340 & 450 & 581 & 417 & 438 \\
Lignin & 2106 & 2451 & 1742 & 1782 & 1897 & 1941 \\
\hline
\end{tabular}

(c) Actual nutrient quality of the same dung sample (values in $\mathrm{mg} . \mathrm{g}^{-1}$ except lignin which is expressed as \% faecal sample by weight)

\begin{tabular}{lcccccc}
\hline $\mathrm{N}$ & 16 & 26 & 20 & 18 & 15 & 13 \\
$\mathrm{P}$ & 0.8 & 1.1 & 1.1 & 1.1 & 0.2 & 0.3 \\
$\mathrm{~K}$ & 2.0 & 2.1 & 2.4 & 0.9 & 1.6 & 2.4 \\
$\mathrm{Mg}$ & 0.6 & 0.5 & 0.4 & 0.3 & 0.5 & 0.5 \\
$\mathrm{Ca}$ & 0.6 & 4.7 & 4.4 & 3.3 & 1.5 & 3.3 \\
Lignin & 31.3 & 34.7 & 31.7 & 31.0 & 29.3 & 30.7
\end{tabular}

requires considerable transformation of the basic data; there is of course potential for error at each stage. The laboured methodology adopted in determination of nutrient status of the diet, with its potential for compounded error, may therefore weaken the readers' confidence in any conclusions drawn from the present investigation. We would note, however, that dietary profiles revealed in Tables $1 \mathrm{a}-4 \mathrm{a}$ are compatible with those derived elsewhere for the same animal species in the same study areas (e.g. Jackson 1977, Putman et al. 1982, Mann 1983). Further, the derived nutrient quality of individual diets (Tables $1 \mathrm{~b}-4 \mathrm{~b}$ ) also show predictable and expected patterns of change. Thus, for all animal species the diet shows an increase in total $\mathrm{N}, \mathrm{P}, \mathrm{K}$ from spring through summer, with a decrease in value of these nutrients towards 
winter. Calcium values show like pattern in Fallow and Sika deer. Conversely, lignin content of the diet shows a gradual decline in the spring, increasing once again over the late summer towards winter. Such observations suggest that despite the possible inaccuracies of the method, the relative nutrient status of the diet so derived is projably acceptable for our purposes.

Comparison (within months) of nutritional quality of the diet of different animal species further boosts our confidence: the fact that the roe deer (Capreolus capreolus), a known "concentrate selector" (Hofmann et al. 1976), consistently shows a higher relative nutrient intake than any other species suggests that in relative terms (all that is required for the present analysis) our values for nutrient status of the diet are valid for our purposes here.

Table 5

Relationships between chemical content of dung and diet. Upper number - correlation coefficients, lower numbers - significance of correlation. NS - not significant at $p=0.1$.

\begin{tabular}{|c|c|c|c|c|c|c|}
\hline & $\mathrm{N}$ & $\mathbf{P}$ & $\mathrm{K}$ & $\mathrm{Mg}$ & $\mathrm{Ca}$ & Lignin \\
\hline Fallow deer & $\begin{array}{l}0.16 \\
\text { NS }\end{array}$ & $\begin{array}{l}0.43 \\
\text { NS }\end{array}$ & $p \leqslant 0.05$ & $\begin{array}{l}0.17 \\
\text { NS }\end{array}$ & $\begin{array}{r}0.67 \\
p=0.1\end{array}$ & $\begin{array}{r}0.63 \\
p=0.1\end{array}$ \\
\hline Sika deer & $p \leqslant 0.05$ & $\begin{array}{l}0.49 \\
\text { NS }\end{array}$ & $p=0.1$ & $\begin{array}{l}-0.06 \\
\text { NS }\end{array}$ & $p \leqslant 0.05$ & $\begin{array}{l}-0.69 \\
\text { NS }\end{array}$ \\
\hline Roe deer & $\begin{array}{c}0.24 \\
p=0.1\end{array}$ & $\begin{array}{l}-0.38 \\
\text { NS }\end{array}$ & $\mathrm{p} \leqslant 0.01$ & $\begin{array}{l}0.56 \\
\mathrm{NS}\end{array}$ & $\begin{array}{l}-0.55 \\
\text { NS }\end{array}$ & $\begin{array}{l}0.79 \\
\text { NS }\end{array}$ \\
\hline Horses & $\begin{array}{l}0.38 \\
\text { NS }\end{array}$ & $\begin{array}{l}0.49 \\
\text { NS }\end{array}$ & $\begin{array}{c}-0.45 \\
\text { NS }\end{array}$ & $\begin{array}{l}-0.47 \\
\mathrm{NS}\end{array}$ & $\begin{array}{l}0.36 \\
\text { NS }\end{array}$ & $\begin{array}{r}0.75 \\
\mathrm{p}=0.1\end{array}$ \\
\hline
\end{tabular}

We may therefore move on to consider the results of the present study in investigation of relationship between faecal chemistry and presumed nutrient content of ingesta. Linear relationships were ound between nutrient content of dung and diet for $\mathrm{N}, \mathrm{K}, \mathrm{Ca}$, amongst the ruminants. Correlations for potassium (K) were statistically signilicant in all cases $(p<0.05)$; correlations for nitrogen were significant ony for Sika deer, just missing statistical significance for roe and fallow deer. Correlations between calcium content of dung and diet were significan (if confidence limits are stretched to $p=0.1$ ) for fallow and sika deer.

Individual significance levels throughout are not particularly strong (due largely to the necessary insensitivity of methods adopted in determining ingesta); the fact that the relationship between dung and diet is shown for the same nutrients in each of three different deer species must however strengthen one's confidence in these correlations. Most striking is the difference in result established between the various deer species and the only monogastric: the horse. Here, the only signi- 
ficant correlation between dung and diet nutrient content was for lignin; yet lignin showed no such relationship in any of the ruminants. Such differences must clearly reflect the different digestive mechanisms of monogastrics and ruminants.

Erasmus et al. (1978) demonstrated from their feeding trials a linear relationship between nutrient content of dung and diet, for lignin and nitrogen. Correlations for lignin in the present study was not found in any of the ruminants; correlations for nitrogen were recorded in all ruminants but were only strictly significant in one case, Sika deer. (Table 5).

It is perhaps somewhat surprising that no correlations were found in the present study for lignin. Lignin, after all, represents the one component of the diet that is virtually indigestible; we might thus expect the majority of the lignin ingested to be voided in the dung producing a linear relationship. Lack of any clear correlation in our results (except for the horse) might thus suggest that the lignin fraction measured by us included other structural carbohydrates as well as lignin and that a variable proportion of these might indeed by degraded hy the ruminant digestive system. The fact that linearity is obtained in relationship between diet and dung for the horse is consistent with such a conclusion: the monogastric digestive tract can digest relatively less than the ruminant of any structural carbohydrate.

The linear correlation suggested by our own results and those of Erasmus et al. between nitrogen content of dung and diet is rather unexpected. Amongst most ruminants, high levels of nitrogen in the diet are potentially toxic and are rapidly eliminated, while at the other extreme, nitrogen retention is greatly increased at low levels in the diet (Robbins et al. 1974, Wales et al. 1975). Thus, in practice, a sigmoid response in nitrogen retention/elimination against dietary nitrogen may be expected. To complicate matters still further, nitrogen retention is also known to be a function of, and strongly dependent upon energy value of the diet (Hungate 1960, Blaxter 1975).

Nonetheless relationship between dietary nitrogen and nitrogen in the dung is shown to be effectively linear for Springbok, Merino and Dorper sheep (Erasmus et al. 1978) and, weakly, for sika, fallow and roe deer (present study). There are two possible explanations for this. The overall sigmoid curve predicted might, over a relatively narrow range of values (such as experienced in the diets of the present study) become effectively near-linear, purely because of the narrow range of values considered. In addition, the nitrogen values of natural forages usually fall at the very low end of the range of dietary quality used in agricultural trials of this sort. Thus, for natural forages, which offer 
a very restricted range in differential nitrogen value, and which in any case fall at the very low end of the scale, it is possible that a linear relationship might obtain between dietary and faecal nitrogen. Such a relationship has now also been noted for wapiti, Cervus elaphus, (Gates \& Hudson 1979; Mould \& Robbins, 1981) and in the snowshoe hare, Lepus americanus (Sinclair et al. 1982).

The current study extends upon the work of Erasmus et al (op. cit.), in investigating the relationship between quality of ingesta and chemical composition of dung with regard to four additional nutrients: P, $\mathrm{K}, \mathrm{Mg}, \mathrm{Ca}$. Linear correlations, significant at the $10 \%$ level were established amongst ruminants for $\mathrm{N}, \mathrm{K}, \mathrm{Ca}$, and in the horse, for lignin. These results suggest that original suggestions of Erasmus et al. that diet quality in terms of lignin and nitrogen could be determined readily from chemical analysis of faecal material, might also be extended to other nutrients. What is curious is that those nutrients for which linear correlation exists between content of diet and dung differ between ruminants and the only non-ruminant studied: the horse. Presumably such differences reflect the different fermentation processes of digestion between ruminant and monogastric animals.

Clearly some form of relationship could be established between nutrient content of ingesta, and residue of that same nutrient in the dung for any nutrient. There is an extensive agricultural literature devoted specifically to studies of metabolism and retention of each major nutrient by domestic animals. Detailed examination of this complex literature would not doubt permit one to establish precise relationships for a variety of herbivore species between nutrient intake and egestion, as we have done in these pages in establishing sigmoid curve for nitrogen release. Some such relationship must exist in every case. But the beauty of the conclusions of Erasmus et al. - amply supported by the results of the present study - is that such complexity is in practice unnecessary: that for many nutrients a linear relationship may be established between content of diet and dung for a variety of free-ranging herbivores.

Acknowledgement. We would like to thank Bob Pratt, Chris Mann, Andy Parfitt and Tim Johnson for allowing use to sequester some of their hard won faecal materials; Rue Ekins and Chris Mann for forage values used in the analyses and all five for stimulating discussion during this study.

\section{REFERENCES}

1. Allen S. E. (Ed.), 1974: Chemical Analysis of Ecological Materials. Blackwell: 1-565. Oxford.

2. Anthony R. G. \& Smith N. S., 1974: Comparison of rumen and faecal analysis to describe deer diets. J. Wildl. Manage., 38: 535-540. 
3. Blaxter K. L., 1975: Energy-protein relationships in ruminants. Proc. 9th Int. Congr. Nutrition., 3: 122-127.

4. Engels E. A. N., van Schalkwyk A., Malan A. \& Baard M. A., 1971: The chemical composition and in vitro digestibility of forage samples selected by oesophageal fistulated sheep on natural pasture of the Central Orange Free State. S. Afr. J. Anim. Sci., 1: 43-4.

5. Engels E. A. N. \& Hyam G. F. S., 1975: Some techniques for measuring animal and herbage production. Publication No. 52, The Fertiliser Society of South Africa.

6. Erasmus T., Penzhorn B. L. \& Fairall N., 1978: Chemical composition of faeces as an index of veld quality. S. Afr. J. Wildl. Res., 8: 19-24.

7. Gates C. C. \& Hudson R. J., 1979: Weight dynamics of free-ranging elk. Univ. Alberta. Agric. For. Bull., 58: 80-82.

8. Goering H. F. \& van Soest P. J., 1970: Forage fibre analyses: (Apparatus, reagents, procedures and some applications). Agriculture Handbook No. 379. Agricultural Research Service, Washington D. C.

9. Hintz H. F., 1969: Review article: Equine nutrition. Comparisons of digestion coefficients obtained with cattle, sheep, rabbits and horses. The Veterinarian, 6: $45-51$.

10. Hofmann R. R., Geiger G. \& Konig R., 1976: Vergleichend-anatomische untersuchungen an der Vormagenschleimhaut von Rehwild (Capreolus capreolus) und Rotwild (Cervus elaphus). Zeitschr. Saugetierk., 41: 167-193.

11. Hungate R. E., 1960: The Rumen and its Microbes. Academic Press, New York.

12. Jackson J. E., 1977: The annual diet of the fallow deer in the New Forest, Hampshire, as determined by rumen content analysis. J. Zool. (Lond.), 181: $465-473$.

13. Johnson T. H., 1984: Habitat and Social Organisation of Roe Deer, Capreolus capreolus. Ph. D. thesis, University of Southampton.

14. Jones D. I. H. \& Hayward M. V., 1975: The effect of pepsin pre-treatment of herbage on the prediction of dry matter digestibility from solubility in fungal cellulase solutions. J. Sci. Fd. Agric., 26: 711-718.

15. Mann J. C. E., 1983: The Social Organisation and Ecology of the Japanese sika deer (Cervus nippon) in Southern England. Ph. D. thesis, University of Southampton.

16. Mould E. D. \& Robbins C. T., 1981: Nitrogen metabolism in elk. J. Wildl. Manage., 45: 323-334.

17. Putman R. J., Edwards P. J., Ekins J. R. \& Pratt R. M., 1982: Food and feeding behaviour of cattle and ponies in the New Forest, Hampshire. Project report to Nature Conservancy Council HF3/03/127.

18. Putman R. J., 1984: Facts from faeces. Mammal Review, 14: 79-97.

19. Robbins C. T., Prior R. L., Moen A. N. \& Visek W. J., 1974: Nitrogen metabolism of white-tailed deer. J. Anim. Sci., 38: 186-191.

20. Sinclair A. R. E., Krebs C. J. \& Smith J. N. M., 1982: Diet quality and food limitation in herbivores: the case of the snowshoe hare. Can. J. Zool., 60: 889-897.

21. Staines B. W. \& Crisp J. M., 1978: Observations on food quality in Scottish red deer (Cervus elaphus) as determined by the chemical analysis of the rumen contents. J. Zool. (Lond.), 185: 253-259.

22. Staines B. W., Crisp J. M. \& Parish T., 1982: Differences in the quality of 
food eaten by red deer (Cervus elaphus), stags and hinds in winter. J. appl. Ecol.. 19: 65-77.

23. Stewart D. R. M., 1967: Analysis of plant epidermis in faeces: a technique for studying the food preferences of grazing herbivores. J. appl. Ecol., 4: 82-111.

24. Stewart D. R. M. \& Stewart J., 1970: Food preference data by faecal analysis for African plains ungulates. Zool. Africana, 5: 114-129.

25. Van de Veen H., 1979: Food selection and habitat use in the red deer (Cervus elaphus L.). Ph. D. thesis, Rijksuniversiteit te Grönigen.

26. Wales R. A., Milligan L. P. \& McEwan E. H., 1975: Urea recycling in caribou, cattle and sheep. 1st Int. Reindeer and Caribou Symp. (Eds. Luick J. R., Lent P. C., Klein D. R. \& White R. G.).

Accepted, January 10, 1986.

R. J. PUTMAN \& G. J. HEMMINGS

\section{CZY JAKOSC DIETY DZIKICH KOPYTNYCH MOZE BYC OKRESLONA NA PODSTAWIE SKEADU CHEMICZNEGO KAEU?}

\section{Streszczenie}

Na podstawie doświadczeń pokarmowych z kilkoma gatunkami kopytnych w Afryce poludniowej, Erasmus et al. (1978) zasugerowali, że pomiędzy zawartością niektórych pierwiastków $w$ diecie $i$ kale tych zwierząt istnieje zależność liniowa, wobec tego analiza chemiczna kału moglaby stanowić prostą metodę określania jakości zjadanego pokarmu. Sprawdzono tę hipotezę na trzech gatunkach przeżuwaczy (daniel, jeleń sika, sarna) oraz wolno-żyjących koniach. Zawartość składników odżywczych $\mathrm{w}$ kale porównywano $\mathrm{z}$ ich ilością w zjadanym pokarmie roślinnym, zrekonstruowanym na podstawie analizy odchođów. Istotna korelację liniowa znaleziono u daniela, jelenia sika i sarny dla $\mathrm{N}, \mathrm{K}$ i Ca. Nie wykazano jej dla $\mathrm{P}, \mathrm{Mg}$ i ligniny. W przypadku koni korelacja taka istniala tylko dla ligniny (Tabele $1-5$ ). 